\title{
The role of Circle women in curbing violence against women and girls in Africa
}

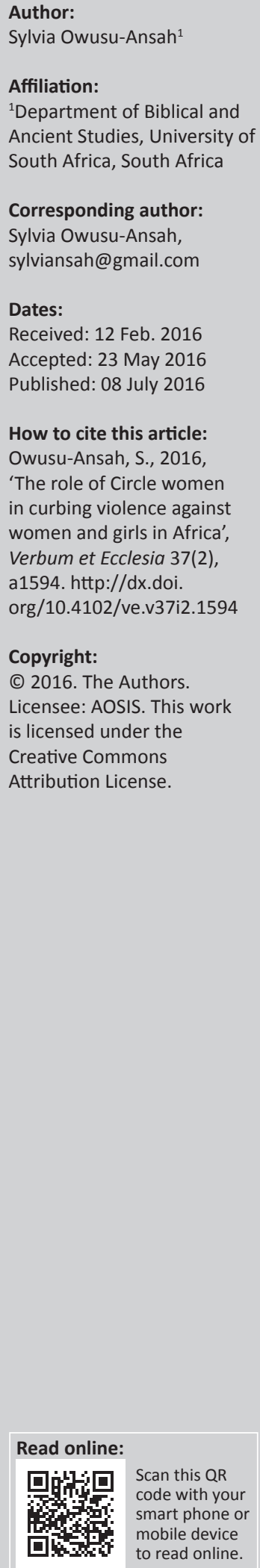

The article looks at the role Circle of Concerned African Women Theologians (the Circle) have played in the struggle to end or reduce the rate at which violence against women and girls occurs in West Africa by highlighting the contributions of older Circle women, especially the initiator of the Circle, Mercy Amba Oduyoye. The initiator of the Circle and other older Circle women have left a remarkable legacy that needs to continue by the current and future generations of the Circle. The background information examines the leadership and mentorship of Mercy Amba Oduyoye and the impact she has made in the lives of African women. The essay then looks at the types of violence that women face in West Africa with the specific contributions of Circle women in the struggle to end violence against women and girls. It then argues that Circle women have played very significant roles both in setting the pace and giving the platform for women activities to minimise gender-based violence against women and girls. Circle women have written and presented papers that have addressed many challenges including HIV and/or AIDS, Girl Child trafficking, Marriage of Minors, and almost all kinds of violence against women and girls. Currently, religious violence threatens the fabric of African nations causing insecurity and panic, women and girls being the most vulnerable. The challenge to the present and future Circle members is to contribute in significant ways towards religious harmony in Africa and beyond. The Circle acknowledges the leadership role of women and encourages them to spearhead the liberation of women as well as empower them to be able to aspire to get to the top or become independent. No one understands what someone else feels better than the person experiencing the ordeal. Women can better understand what they go through and also have the passion to strive towards liberation.

Intradisciplinary and/or interdisciplinary implications: In this article, the discipline of practical theology combines with elements of social science and Gender Studies, bringing out the Circle's contribution towards the eradication of religious and cultural and gender violence against women and girls in Ghana and Africa.

\section{The legacy of older generations of Circle women}

The Circle of Concerned African Women Theologians, known as 'the Circle', is a multi-religious association of women theologians in Africa. The Circle began with the vision of its initiator, Mercy Amba Oduyoye of Ghana. She saw the need to call on other women theologians in Africa to face together with her the challenges of the African woman theologian. According to her, in 1974 she found herself as the only female theologian among her colleagues. As she pondered over what it meant to be the only woman theologian among men, the expectations of her colleagues to speak for African women became too enormous for her to bear alone. In a period of 5 years, she sought out other female theologians in other parts of Africa. She searched through theological colleges, universities and other institutions. Through her ecumenical connections, she got in touch with Isabel Johnson of All Africa Conference of Churches (AACC) Women's Desk, and Daisy Obi of the Christian Council of Nigeria, director of the Institute of Church and Society. Together with these women who whole-heartedly embraced the vision of togetherness, the first All African Women in Theology Conference was organised in Ibadan in the year 1980.

The opportunity to revisit the vision was provided by her being in World Council of Churches (WCC) in 1987 as Deputy General Secretary for program planning and co-ordination. She used this position to call a group of some African women that became the planning committee for the 1989 convocation at Accra. The planners of the conference who later became the core of the Circle include Elizabeth Amoah, Betty E. Ekeya, Rosemary Edet, Grace Eneme, Rev. Zoe-Obianga, Musimbi Kanyoro, Brigalia Bam and Bernadette Mbuy Beya. John Pobee, then a staff member of the WCC Program for Theological Education (PTE), was very helpful to the founding and development of the Circle as he provided administrative service and helped to administer the 
funds raised by Oduyoye for the Pan-African conference in 1989. Oduyoye and Kanyoro (1990:2) captured the proceedings of the convocation of African women theologians in 1989. This conference, termed a 'Convocation' (calling together), decided to found 'a Circle of Concerned African Women Theologians and also spelled out its 10 concerns' (Oduyoye 2001). The Circle was inaugurated in Accra, Ghana, in 1989. Membership includes theologians from African Traditional Religion, Islam, Christianity and Judaism. There are Circles in South Africa, Ghana, Nigeria, Kenya, Cameroon, DRC, Mozambique, Angola, Ethiopia and other parts of Africa. Nine years after the first conference in Ibadan, another conference was organised in 1989 in Accra, Ghana. It could be said that the Circle was founded by the planning Committee of the Accra 1989 Convocation. However, its initiator was Mercy Amba Oduyoye. In 1996, the Circle elected Musimbi Kanyoro as the general coordinator supported by a coordinating committee. Musimbi Kanyoro had been the key collaborator of Mercy Amba Oduyoye in the period before 1988 and 1996.

Ever since its inception, the Circle has been very active in challenging and exposing cultural principles and practices that undermine the dignity of women and has undertaken to unmask 'disempowering religious teachings' and beliefs. According to Mercy Amba Oduyoye, the Circle has motivated African theologians to pay more attention to what culture and religion do in women's lives. The Circle incorporates women theologians of different religious affiliation since the concerns being addressed affect all the members of the African communities irrespective of their religious affiliation. This has been very innovative as Rabiatu Ammah, an astute member of the Circle in Ghana, has been involved in assembling Muslim women in Ghana and assisted in the formation of the 'Federation of Muslim Women's Association of Ghana (FOMWAG)' with the aim of promoting the education of (Muslim) girls. Circle women in other parts of Africa are also actively involved in activities that promote the overall vision of the Circle.

For example, the Circles in Kenya, South Africa, Democratic Republic of Congo, Nigeria and other areas are actively involved in research, writing and publication. The Nairobi Circle has established a research centre at Limuru Theological Seminary, now St Paul's University, Limuru, 'to make women's writings available to both students and the general public'. This Circle, which was promoted by the Commission of Women and Ministerial Formation, has been very active in encouraging the ordination of women under the leadership of Nyambura Njoronge and Esther Mombo. In June 2014, the Limuru Circle (at St. Paul's Seminary) celebrated 30 years of female ordination to commemorate the success and achievements of the East African Circle towards female inclusiveness and church leadership. Some of the women who shared their stories were Bishops and Very Rev. Ministers in their various denominations. The Circle has chapters in some French speaking countries in Africa, and the research activities of these chapters are being coordinated by the branch at the Democratic Republic of Congo. Helen Yinda from Cameron coordinated the French speaking countries and for years acted as the interpreter or translator to facilitate communication. Her D. Min thesis and other books are on violence against women. The Circle has study commissions working on themes like religion and pluralistic cultures, biblical and cultural hermeneutics, and theological and ministerial formation of women. The goal of the Circle is to provide a voice for African women through research, writing and publication - a vehicle for addressing issues of gender violence, sexism and gender inequality in the religious community and in the society.

The Circle employs a theology of relations (Landman 1998:15). Thus, its theology is society sensitive, in that they replace the hierarchical relations of patriarchal theologies and customary practice with relations based on mutuality. African women's theology is a theology of interrelatedness, that is, they acknowledge the interrelatedness of men and women and of people and nature; this means that it is ecology sensitive. It is also culture sensitive as much as it encourages dialogue between cultures and within cultures in order to criticise what is oppressive and to develop what is liberating in African customs. African women theologians implement their research findings through a ministry of storytelling. Ideas are conveyed through a narrative theology using biblical stories such as Hannah' story, Jezebels story, Mrs Job's story, Samson's mother's story and many such stories from the Bible. The Circle's Biennial Institute of African Women in Religion and Culture was inaugurated for a sabbatical period (1989-1996). During this period, African women were expected to concentrate on publishing literature from the base of religion and culture to enrich the critical study and empowering of the practice of religion in Africa (Oduyoye \& Kanyoro 1990). This led to the establishment of the Biennial Institute and the production of AMKA, an occasional newsletter of the Circle. It surveys the role of religion and culture in the lives of African women. Areas of concentration include the following: the rooting of Christianity in Africa, particularly Christian doctrine and discipline; the roots of the Levirate marriage; single women parents in Africa; women as victims of sex tourism; sexuality and religion etc. (Kanyoro 1991). In AMKA issue Number 2, Martha Mukangara (1992:7-13) discusses 'Churches Solidarity' with women in Zimbabwe. Other Circle women who have addressed issues of violence against women in religion and culture include Nyagondwe (2005) and Lasebikan (2001). Prominent among the contributions of Circle women in addressing issues of violence against women in religion and culture are the publications of Mercy A. Oduyoye (1986, 1995, 1996, 1997).

The goal of the Circles' Biennial institute was to create a forum for women whose interests were in the area of how religion and culture function in the lives of women. It also aimed at publishing documents for the academic study of religion and culture, contributing to research that leads to policies affecting African women's development and participation in religion and society, working towards the inclusion of women's studies in religion and culture in the 
research carried out by institutes of African studies at African universities and other tertiary institutions, and enabling African women in religious and cultural studies to contribute to cross-cultural studies of contemporary women's issues. Other goals include establishing a network of women to monitor women's interests in this area and to serve as advocates for the inclusion of women in all deliberations in the field of religion and culture, and to promote the inclusion of specifically women's concerns in the theory and practice of evangelism. They desire to do theology that seeks to be relevant to the urgent concerns and issues of the African continent and to make Africa's voice heard on the global terrain. African women's theological discourse is described by Mary Gerald Nwagwa as 'a critical theology directed towards the full liberation of women from shackles of male domination and patriarchal systems' (Kemdirim \& Oduyoye 1998:94). From 1996, the biennial institute was discontinued in preference for more flexible ways of organising their efforts, concentrating on interest groups as demonstrated in the study commission of Nairobi $1996 .{ }^{1}$

The Circle links up with other Third World persons working on these issues. Several members of the Circle are also members of the Ecumenical Association of Third World Theologians and some have served in its key positions of Executive Secretary, Theresa Okwe; Vice President, Bernadette Mbuy Beya. Mary John Maranzan and MAO were the first coordinators of its Women's Commission. Mercy Oduyoye was President of the Association.

Like feminists in other parts of the world, the African women theologians also read biblical texts from their own perspective, empowering women through 'constructive theology' (Amoah 1997:v-ix; Phiri 2000:329). Contemporary issues affecting women in Africa identified by the Circle include patterns of power and authority. They have noted that in 'our contemporary society, the power and authority are often in the hands of men'. They have also identified certain taboos, norms and laws that forbade women from doing and participating in certain activities. They have pointed out among other things that these taboos may no longer hold for some women. However, other forbidden areas linked to the modern job sector do exist. For example certain jobs are believed to be more suitable for men than for women (Oduyoye \& Kanyoro 1990:19). They discuss and deliberate on issues of child and women abuse, murders, incidents of maiming, child trafficking, sexual exploitation, sex tourism and prostitution. They also evaluate what has been said about women. Violence against women and girls is one of the major concerns of all Africans that the Circle has addressed from all angles through the writing and publication of various articles, books and seminar presentations (Akintunde \& Labeodan 2002:1-129). Through the sensitisation of the Circle, other women's groups and initiatives have sprang up also addressing African women's needs, especially domestic violence. One of such groups is

1.The Women in Religion and Culture study Commission based in Accra was developed by its' coordinators, Mercy Amba Oduyoye and Elizabeth Amoah, supported by the Circle women in Ghana into the Institute of Women in Religion and Culture. the Ark Foundation based in Ghana advocating for abused and marginalised women, and Moslem women in Ghana have focused on the education of women and girls as a means to lifting women's self-image to enable them to resist and report violence.

\section{Violence against women and girls}

Violence against women and girls is assuming alarming proportions across the world. It occurs during times of conflict and during periods of peace. It continues to manifest itself in harmful cultural practices, abuse during pregnancy, spousal murder, psychological and physical violence among others. Violence is perpetrated by and against people of all social backgrounds (Essel 2013:n.p.). The situation in Ghana is not different. Research done in 1998 by Gender Studies and Human Rights Documentation Centre showed 1 in 3 women suffered physical violence, $27 \%$ of women had been sexually abused and 5\% of women had been circumcised (Essel 2013:n.p.):

More than a decade after the research, the situation has not changed. Statistics from the Domestic Violence and Victim Support Unit (DOVVSU) indicate there were 986 defilement cases in 2010. This figure jumped to 1,176 in 2011. In 2012, the country recorded 10 spousal murders, the majority being husbands killing wives. (n.p.)

\section{What is violence against women?}

Violence against women and girls is defined as any act of gender-based aggression that results in or is likely to result in physical, sexual, political, economic, civil, psychological and emotional harm or suffering to women and girls. This includes threats of such acts as denying a woman or a girl of her liberty whether occurring in public or private place. Physical violence may be described generally as any act or action done intentionally to inflict pain or cause harm to the body. Examples are slapping, beating with hands and objects like dog chains, pestle, bicycle tire, kicking, burning and many others. Injuries that women suffer from physical violence include bruises and body aches, open wounds, broken bones, swollen eyes, blood from ears and swollen face (Appiah \& Cusack 1999:19). Psychological violence includes verbal threats and unfaithfulness to women resulting in extramarital sexual affairs with girls and other women. Denying women the right to be themselves and the rights to pursue careers or work outside the home and confining them to a specific space also could be termed as psychological violence. All such acts of sexual behaviours and relationships without the consent of the woman may be termed as sexual violence against women (Appiah \& Cusack 1999:21-28). Sexual violence includes sexual harassment. The Collins English Dictionary - complete and unabridged digital edition defines sexual harassment as: 'unwelcome sexual advances made by an employer or superior, especially when compliance is made a condition of continued employment or advancement', or 'the persistent unwelcome directing of sexual remarks and looks, and unnecessary physical contact at a person, usually a woman, especially in the workplace' (Collins 2012:n.p.). Sexual harassment can be both verbal and physical. It ranges from personal remarks to a sexually 
serious assault. It can assume the guise of a joke with embarrassing sexual overtones or pressure to exchange sexual favours for career advancement ( $\mathrm{O}^{\prime}$ Connell n.d.).

Basically, four main factors have been identified as causes of violence against women and girls. These include economic inequality between men and women, violent measures of resolving conflicts, male authority and control (power) and domination of the woman, restrictions on women's ability to leave the family setting or work outside the home and, above all, violence against women could be described as a violation of women's rights. From the theological point of view however, violence against women or fellow human beings among other things could be attributable to the sinfulness and selfishness of the human nature. Looking at the above factors, violence against women and girls can be reduced and consequently eliminated only through fundamental social and attitudinal changes at the family, community, state and international levels.

Women need more education to know that it is important to report incidents of threat and assaults against them to places where perpetrators could be punished. Some women do not report especially their husbands because they are the bread winners and if they end up in prison their children would not be catered for. Oduyoye wonders how love can be manifested in destruction (Personal Conversation: June 11, 2005):

There are many myths blaming women for the violence, which is perpetrated against them. Most of these trivialise the seriousness and the effects of the experience. In cases of sexual assault and rape, research has shown that the primary motivating factor is the non-sexual needs including anger and power, to dominate and degrade women, any woman - not for sexual gratification. Anybody can be the target for sexual assault regardless of age or circumstance. Women are the main victims but occasionally men too are assaulted. The belief that rape is a sexual act contributes to the idea that the victim is in some way responsible for the attack. Women censor their activities in an attempt to avoid being targeted, but this does not prevent women of all ages, in diverse circumstances being sexually assaulted. Victims fear that they will not be believed, and this contributes to the silence that continues to surround crimes of sexual violence. It is one of the most devastating of human experiences. The terror, helplessness, humiliation and pain involved result in severe distress, which has great impact on the victim's life. (O'Connell n.d.:n.p.)

\section{Works of older Circle women on violence against women and girls}

To highlight the real-life situations and cases of violence against women and girls, some Circle members, led by Mercy Amba Oduyoye and Elizabeth Amoah, undertook an exercise that led to interviewing some women and girls in Accra, Ghana, and the report published in a book titled Too Painful to Tell (Amoah 2001:1-129). This book has been used in theological institutions and Gender Studies classes in Ghana and beyond for discussions on the subject of gender violence. A summary discussion of the book in my Gender Studies classes would explain the meaning of violence against women and girls while at the same time showcasing Circle women's contribution towards curbing gender violence in West Africa. The book has three natural divisions into three chapters, each of which reports particular types of cases. My Gender Studies class was divided into three groups to discuss each chapter of the book. I present the discussions of group two of the discussions group.

The 19 cases reported in this section (Chapter 2 of Too Painful to Tell) portray the painful experiences of some women in their marital lives or relationships. They reflect the general trend in the society where some men see women as tools in their hands for the achievement of their selfish ends. The attitudes of some of them show that they have no respect for the being, intelligence, feelings and concerns of women. A closer look at the cases gives further explanation.

\section{The cases}

In three of the cases, the men practically saw the women as a means to satisfy their sexual desires and nothing more. One girlfriend was beaten because she refused to abort a pregnancy. The man who impregnated her refused responsibility for the pregnancy because he claimed he used condom. Three women were assaulted because they refused their husbands sex. The last woman was used by her village school teacher while in class, produced six children with him, only to be dumped together with her children when the teacher was transferred to the city. All six children went wayward. With the second group of women, one was punished any time she got home after 8:00 p.m. Another has her former boyfriend keeping surveillance on her and pestering her to continue in the relationship even though he had married another woman. His reason was that he had spent a lot of money on her. The next group had their husbands being unfaithful. When they were found out, the men tried to put forward similar allegations against their wives and, without any proof, turned round and brutally assaulted the women. One has her clothes and cash also burnt and the other was beaten till she lost consciousness. In four of the cases, instead of finding solutions to problems in the marriage, the men took to beating their wives. One woman was stabbed and slashed with a knife and another became partially blind from such beatings. In one case, the man simply left the greater part of the financial burden on the woman even though he was well to do. In two cases, the men wickedly and continually defiled their teenage daughters forbidding them to tell anybody or be killed.

The discussions of the group maintained that the attitudes of these men do not speak of one human being seeing the other as someone to be respected and honoured; one with intellect and therefore can be reasoned with; one whose ideas and views should be valued; somebody with sentiments that should be considered. The women are made to appear like mere objects in the hands of the men, to be treated any way these men like. The women are abused and misused as if they are not humans and therefore fall outside the human rights laws of the land. Sadly, many of them have resigned themselves to this fate in order to preserve their husbands, so 
they simply take the beatings. A lot of women under such conditions lose their self-worth and are unable to live out their potentials and gifts. The group concluded that the picture that these attitudes portray is too bizarre to simply let go. The issues need to be addressed, not just because the women are suffering but also because some brutish tendencies in men must be acknowledged and solutions found to help them out of their predicament and for sanity and peace to prevail in the community. The effects of such behaviour adversely affect the advancement of the entire community.

\section{A visit to Gambaga Witches' camp in northern Ghana}

The Circle women on various occasions have visited and encouraged the marginalised and rejected of our societies and sought ways to alleviate the sufferings that such women and girls go through. An example of such is the Trokosi victims in Ghana. The Trokosi is a religious servitude designed to get young girls to serve in shrines to pay for an alleged debt or punishment that is likely to come upon the family of the victim for a crime committed by a member of the family, dead or alive. One of the original Circle members, Dinah Abbey Mensah, researched Trokosi, educated her Circle members and ran workshops on it in the Eastern Region of Ghana where this is practiced. Dinah Abbey Mensah has documented her research but it is yet to be published. Some of the older Circle members, led by Mercy Amba Oduyoye, visited the Gambaga Witches camp in northern Ghana, a place where older women alleged to be witches driven from their homes and neglected are kept to protect them from being murdered or injured by those who accused them. From the above examples, we are able to establish that gender-based violence takes place in all areas of human endeavour and it happens to both women and girls. The younger and upcoming generations of the Circle need to take up the mantle from the older generation in order to continue to carry out the vision of the Circle.

\section{A challenge to current and younger generation of Circle theologians}

The article has highlighted the work and achievements of older generation of Circle theologians, bringing to the fore how they have impacted Africa and the world at large. Through research, writing and publications, these women have addressed issues of female abuse and marginalisation, gender disparity and brought so many women to occupy positions of prominence. They have also served as mentors and leaders to many women who otherwise would not have reached where they are now in their academic endeavours. The challenge to younger and current generations of the Circle is to continue to follow the trend to lift up the feeble knees and encourage the weak and hopeless, to take up research and publication to another level, and to research into themes that are relevant to current human and women's need. Such issues continue to stare glaringly at us and threaten the very fibre of African communities and societies. The complex problems of religious conflicts and community unrest and disharmony are before us. Such situations endanger the lives of women and children. Such conditions as have been witnessed in Nigeria recently when women and young girls were abducted, are a worry for all Africa, and the Circle demands concerned women to add their voices through research and publication with the aim of encouraging religious harmony and peaceful coexistence. The legacy left by the older generation of Circle theologians through hard work and selfless sacrifice and good will must not be left to die despite current challenges confronting the Circle community. All and sundry are invited to come on board to contribute their quota in making sure that the vision of the Circle survives for many more generations.

\section{Conclusion}

Women have seen all kinds of limitations in every society and epoch from early centuries and generations to recent times. In all these periods, some women have stood firm to fight for their rights or for the rights of other women. Liberation for women has seen so many faces in the history of humankind. So many women and men have been used as instruments to bring about some changes in the life, status and restoration of women to their rightful positions as God intended for them. Women's organisations have stood and fought for women's rights throughout the centuries. The Circle of Concerned African Women Theologians is one of such women's groups. The Circle researches into issues on culture and religions and bring them to bear upon women's lives and situations. Themes that have been researched and campaigned within African women's theology include domestic violence, gender disparity, stereotypes, sexuality, discrimination, sexism, disempowering language, patriarchy, equality and education. Currently, religious violence threatens the fabrics of African societies posing a great danger to women and children (recent Boko Haram abduction of young girls and women). There is a passionate call to current and younger generations of the Circle theologians to contribute towards religious harmony in African societies and the world at large. It is our duty to strip off the masks and give voice to what they hide.

Since the establishment of the Circle, it has worked hard and penetrated through all forms of opposition to achieve some of its objectives such as the incorporation of African women theology and women issues in the curricula of theological institutions and seminaries. It has been found that throughout the centuries until today, women have made several advancements on the road to their emancipation. However, with the present development and improvement in the conditions of the women, they have not reached full legal and recognisable equality with men. Attention has to be called to the efforts of both men and women who necessarily are interested in the progress of women. The attempt to free the oppressed and marginalised within the society should be backed by all if the world is to become a better place to live in. Each one of us was born by a woman. The woman's cry is humanity's cry as humanity's cry is the woman's cry. 


\section{Acknowledgements}

Competing interests

The author declares that she has no financial or personal relationships which may have inappropriately influenced her in writing this article.

\section{References}

Akintunde, D. \& Labeodan H. (eds.), 2002, Women and the culture of violence in traditional Africa, Ibadan, Oluseyi Press Ltd.

Amoah, E., 1997, Where God reigns: Reflections on women's world, Sam- Woode Ltd, Accra.

Amoah, E., 2001, Poems of Mercy Amba Oduyoye, Sam-Woode Ltd, Accra-North.

Appiah, D.C. \& Cusack, K., 1999, Violence against women, Yamens Printing and Packaging Ltd., Accra.

Collins, W. (ed.), 2012, Collins English Dictionary, viewed 01 February 2016, from http://www.dictionary.com

Essel, P.I., 2013, Effects of violence against women in Ghana, viewed n.d., from https://www.womankind.org.uk/blog/detail/our-blog/2013/03/18/effects-ofviolence-against-women-in-ghana

Kanyoro, M.R.A., 1991, AMKA: An occasional newsletter of the Biennial Institute of African Women in Religion and Culture, 1. Sam- Woode Ltd, Accra.
Kemdirim, P.O. \& Oduyoye, M.A., 1998, Women, culture and theological education, Snaap Press Ltd, Enugu.

Landman, C., 1998, 'The implementation of biblical hermeneutics', in M. Oduyoye (ed.), AMKA, 4A, p. 14, SAM-Woode Ltd, Accra.

Lasebikan, E., 2001, A general overview: African culture and the quest for women are right, Oluseyi Press Ltd, Ibadan.

Nyagondwe, B.R., 2005, Women of Bible and culture: Baptist convention women in Southern Malawi, Kachere Series, Zomba.

O'Connell, A., n.d., Praying and Working for the Ordination of Women in the Roman Catholic Church, viewed n.d., from http://homepages.iol.ie/ duacon/violence.htm?

Oduyoye, M.A., 1986, Hearing and knowing: Theological reflections on Christianity in Africa, Orbis Books, New York.

Oduyoye, M.A., \& Kanyoro, M. (eds.), 1990, Tabitha Qumi: Proceedings of the convocation of African women theologians 1998, Sam-Woode Press, Accra.

Oduyoye, M.A., 1995, Daughters of Anowa: African women and patriarchy, Orbis Books, Maryknoll, New York.

Oduyoye, M.A., 1996, 'Feminist theologies: Africa', in L.M. Russell \& J.S. Clarkson (eds.), Dictionary of feminist theologies, pp. 100-102, Westminster John Knox Press, Louisville, KY.

Oduyoye, M.A., 1997, Transforming power: Women in the household of God, SamWoode Ltd, Accra.

Oduyoye, M.A., 2001, Keynote Address: African culture and the quest for women's right, Oluseyi Press Ltd, Ibadan.

Phiri, I.A., 2000, 'Empowering of women through the Centre for Constructive Theology', International Review of Mission 89(354), 329-337. http://dx.doi. org/10.1111/j.1758-6631.2000.tb00210.x 